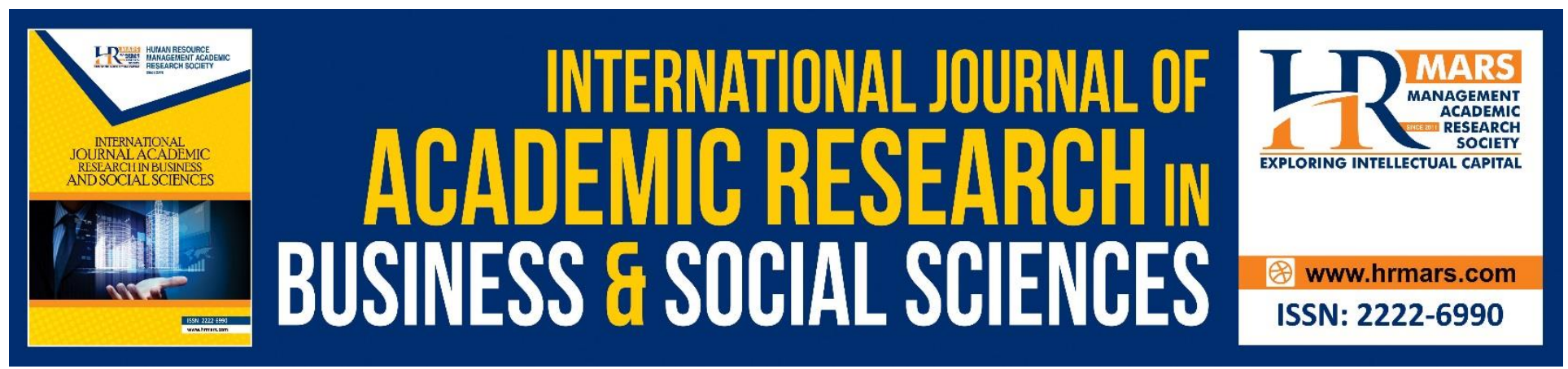

\title{
A Review on the Rhetorical Structure and Linguistic Features of Corporate Annual Reports
}

Shabnum Sayyed Hussain, Afida Mohamad Ali, Zalina Mohd Kasim, Ilyana Jalaluddin

To Link this Article: http://dx.doi.org/10.6007/IJARBSS/v10-i9/7591

DOI:10.6007/IJARBSS/v10-i9/7591

Received: 15 June 2020, Revised: 18 July 2020, Accepted: 21 August 2020

Published Online: 19 September 2020

In-Text Citation: (Hussain, Ali, Kasim, Jalaluddin, 2020).

To Cite this Article: Hussain, S. S., Ali, A. M., Kasim, Z. M., Jalaluddin, I. (2020). A Review on the Rhetorical Structure and Linguistic Features of Corporate Annual Reports. International Journal of Academic Research in Business and Social Sciences. 10(9), 236-256.

Copyright: (C) 2020 The Author(s)

Published by Human Resource Management Academic Research Society (www.hrmars.com)

This article is published under the Creative Commons Attribution (CC BY 4.0) license. Anyone may reproduce, distribute, translate and create derivative works of this article (for both commercial and non-commercial purposes), subject to full attribution to the original publication and authors. The full terms of this license may be seen at: http://creativecommons.org/licences/by/4.0/legalcode

Vol. 10, No. 9, 2020, Pg. 236 - 256

http://hrmars.com/index.php/pages/detail/IJARBSS

JOURNAL HOMEPAGE

Full Terms \& Conditions of access and use can be found at http://hrmars.com/index.php/pages/detail/publication-ethics 


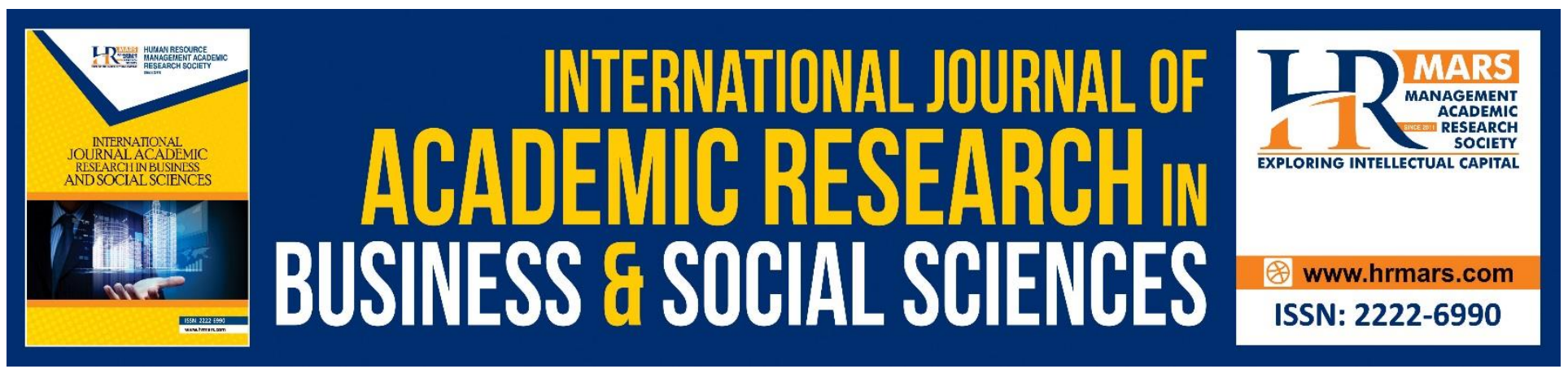

\title{
A Review on the Rhetorical Structure and Linguistic Features of Corporate Annual Reports
}

\author{
Shabnum Sayyed Hussain, Afida Mohamad Ali, Zalina Mohd Kasim, \\ llyana Jalaluddin \\ Department of English, Faculty of Modern Languages \& Communication, Universiti Putra Malaysia, \\ 43400 Serdang, Malaysia. \\ Email: afida@upm.edu.my
}

\begin{abstract}
Corporate annual report (CAR) is a communicative genre written by specialists in corporate companies. Over time, many linguistic studies have been conducted on this genre from various perspectives. This review paper critically examines studies on CARS, specifically on the rhetorical structure and linguistic features used in the genre. Based on the major findings of the studies reviewed in this paper, it can be argued that the writers of this professional discourse embellish the companies' reputation with frequent usage of positive language features and minimal negative aspects. In addition, corporations claim credit and responsibility for positive events but in the case of negative events, responsibility is evaded. Finally, CARs are essentially reporting genres and structurally different from other promotional genres due to intentionally inter-discursive appropriations that are practiced in order to report and promote the companies.

Keywords: Corporate Annual Reports, Corpus Analysis, Genre Analysis, Rhetorical Structure, Linguistic features.
\end{abstract}

\section{Introduction}

Corporate annual report (henceforth, CAR) is a communicating or reporting genre that is written by the expert members of the respective company and briefed by a company executive. Companies publish these documents each year and they are freely, and easily available for the public on the company's website. In general, these multimodal messages appear to serve the wide variety of audiences such as customers, staff, stakeholders and shareholders in much the same way in an attempt to keep them informed or updated on the companies' state of affairs or performance and their latest progress and developments. Nevertheless, a closer reading of these reports reveals that they mainly target the interests of their specific, non-specific, or internal and external stakeholders and investors (Breeze, 2013). In addition, CARs are contemporary report-types that incorporate both qualitative and quantitative data. Qualitative elements consist of corporate social responsibility reports while the quantitative elements include financial reports, highlights and statements. Thus, this informative business document is comprised of "several types of genres and text-types within it 
INTERNATIONAL JOURNAL OF ACADEMIC RESEARCH IN BUSINESS AND SOCIAL SCIENCES Vol. 10, No. 9, 2020, E-ISSN: 2222-6990 @ 2020 HRMARS

or pieces of texts serving more than one text-type" (Palmer-Silveira \& Ruiz-Garrido, 2007, p.151). These sub genres or subordinate text types are intertextually (Tardy, 2003; Fox, 2006) related to one another. They are embedded in an overarching text type in a way that every text type seems complete in its entirety. All sub genres contribute in the overall communicative purposes of the full report.

As a professional genre, CARs mainly supply information on the company's operational performance and financial position besides helping the company maintain its image via a positive, progressive philosophy and high confidence in its future prospects (Malavasi, 2005; Garzone, 2004; Hyland, 1998). Diachronic research have shown that CARs have changed over time from "a financially driven, statutory document toward a more design-oriented document" (Beattie et al., 2008, p.186) and among other functions, prominence is given to its promotional function (Ditlevsen, 2012b; Beattie et al., 2008). The CAR is now widely used as a public relations tool by businesses to create a strong brand image and foster trust (Rutherford, 2005; Beattie et al., 2008; Malavasi, 2010; Ditlevsen, 2012b; Breeze, 2013). Nowadays CARs can be seen not only as honest and objective state of the company's affairs but also used as promotional and public relations tools to display a positive representation of the company and promoting trust (Hyland, 1998; Rutherford, 2005; Beattie et al., 2008; Malavasi, 2010; Ditlevsen, 2012a; Breeze, 2013). As Ditlevsen (2012a, p.379) observed that in the CAR "a company displays its successes and the investment potential of its shares in order to give an impression of its ability to succeed in the future". By highlighting the positive attributes, aims and values (Breeze, 2013), companies discursively construct a good relationship with their stakeholders to build trust and confidence in the company and its management (Malavasi, 2010, p.212; Breeze, 2013, p.84). This transition can be evidenced in the CARs by adding multimodality, graphs, more pictures, number of pages and texts (Garzone, 2004; Beattie et al., 2008; Ditlevsen, 2012b). As noticed by Beattie et al. (2008, p.183), these impression management devices have been used "to convey a more favorable impression of the organization than is warranted". Therefore, it is a "complex and colorful publication" (Breeze, 2013, p.85).

Prior research on CARs (Bhatia, 2010) and the genres of CSR reports (Beattie et al., 2008; Bowers, 2010; Skulstad, 2010; Mason \& Mason, 2012; Ditlevsen, 2012b; Bhatia, 2012) also considered these text types as promotional genres. In his analysis of Hong Kong CARs, Bhatia (2010, p.38), asserts that "corporate annual reports and other disclosure documents seem to be changing in their function from 'informing and reporting' to increasingly 'promoting' the companies by a strategic underplaying of corporate weaknesses; often 'bending' the norms of corporate disclosure genres". Skulstad (2010, p.196) for example, states that CSR reports hardly represent a genuine picture of the environmental effects of the business. Rather, they are a customary attempt to maintain an optimistic image of the company and counter externally constructed images that can harm their business. Similarly, Mason and Mason (2012, p.486) affirms that the selection and organization of micro and macro discursive elements of CSR reports are planned in this way to conceal the negative traits of the company by highlighting the positive parts. Bhatia (2012) states that in banking and aviation-related CARs, the most prevalent type of discourse reflects upon the promotion of the company image using discourse of goodwill and self-justification e.g. company engagement with society and attributing company actions to external pressures. 
INTERNATIONAL JOURNAL OF ACADEMIC RESEARCH IN BUSINESS AND SOCIAL SCIENCES Vol. 10, No. 9, 2020, E-ISSN: 2222-6990 @ 2020 HRMARS

In general, CAR is considered a 'hybrid' genre consisting of informational and persuasive elements (Breeze, 2013; Malavasi, 2010; Rutherford, 2005; Garzone, 2004; Bhatia, 2004). It can be regarded as a mixed or hybrid genre (Bhatia, 2004) containing elements of reporting i.e. arguments and narrations, and promotional genres, i.e. evaluations and descriptions. In this respect, different sections in CARs play different roles. Some sections are devoted to promoting a positive image of the company, while others have a primarily informative function (Breeze, 2013, p.87). For example, narrative sections in CARs are considered more promotional because they contain discretionary information. Among narrative sections, the CEO letter, which normally contains the introduction of the report and overview of the company's performance, is constructed explicitly optimistic and rhetorical (Garzone, 2004, 2005; Breeze, 2012; Fuoli, M. 2016; and Hyland, 1998). On the other hand, mandatory sections such as audited financial statements present a more objective, neutral and technical tone (Breeze, 2013, p.87). Additionally, most of the sections in CARs include a more positive tone, frequent hedging expressions, technical language and greater use of pictures (Breeze, 2013, p.88-100).

The discussion above on contemporary CARs indicates that this genre is more than just "getting things done" (Swales \& Rodgers, 1995, p.226). Rather, it can be acknowledged as an international and versatile promotional management tool that projects corporate identity, loyalty as well as norms in the workforce. Nowadays, CARs are used as promotional tools because they are persuasive in nature by ways of attracting new customers or maintaining shareholder's confidence and support in the company. Literature has shown plenty of linguistic research on CARs from many perspectives. Several corpus-based and genre-based research have been conducted on specific generic and promotional features of CARs. Some of them considered CARs as the most prevalent type of discourse that reflects a company's positive image by strategically underplaying corporate weaknesses (Skulstad, 2010; Bhatia 2010; Bhatia, 2012; Bowers, 2010; Mason \& Mason, 2012). Other studies include the textual realization of corporate vision (Jameson, 2000; Thomas, 1997; Kohut \& Segars, 1992), narrative analysis (Jameson, 2000), the presenting of good news vs. bad news (Thomas, 1997), observations on rhetorical strategies (Frownfelter-Lohrke \& Fulkerson, 2000), how different rhetorical strategies are used to appropriate genres in order to fulfill their communicative purpose (Parsons, 2008; Fuoli 2012; Alexander, 2009; Breeze, 2012, 2013; Caimotto \& Molino, 2011; Mason \& Mason, 2012), discourse and genre studies (Rutherford, 2005; Garzone, 2004; Bhatia, 2013; Bowers, 2010; Mason \& Mason, 2012; Nickerson \& De Groot, 2005), the use of different lexico-grammatical features (Kohut \& Segars, 1992; Malawasi, 2005; Thomas, 1997; Clatworthy \& Jones, 2006; De Groot, et al., 2006; Conaway \& Wardrope, 2010), differences and intercultural differences in styles of writing either the full annual report (Wang et al., 2012), or sub genres of CARs for example: operating and financial review (Rutherford, 2005); the CEOs' letter (Hyland, 1998a; Conaway \& Wardrope, 2010), tax computation letters (Flowerdew \& Wan, 2006), earnings presentations vs earnings releases (Camiciottoli, 2009), auditors' reports (Flowerdew \& Wan, 2010), letters to shareholders (Dragsted, 2014), CEOs' messages (Ngai \& Sing, 2014), and Malaysian CEOs' statements in CSR (Rajandran \& Taib, 2014). Other than that, recent non-linguistic based studies (Pelikanova, 2019; Vithana, et al., 2019; Myskova \& Hajek, 2019; Parshakov \& Shakina, 2020; Dang, et al., 2020; Surdu, et al., 2020) have also examined the CAR and its sub-genres. A sizeable review of studies are also present on different aspects of CARs (Jianguo, 2012; Mobasher, et al., 2013; Wang, 2016; Ali \& Isa, 2018). However, the detailed review of CARs mainly on the rhetorical structure and linguistic features have received minimal attention. Yet, these 
INTERNATIONAL JOURNAL OF ACADEMIC RESEARCH IN BUSINESS AND SOCIAL SCIENCES Vol. 10, No. 9, 2020, E-ISSN: 2222-6990 @ 2020 HRMARS

rhetorical linguistic forms serve various rhetorical purposes of persuasion and promotion of the corporate world. Therefore, this review paper critically examines language-related studies that have been done on CARS to ascertain the communicative functions, rhetorical structure and linguistic features used in the genre. This main research objective of the study is further classified into the following sub-objectives;

- To examine how far corporate discourse embellishes the corporations' reputation by using various linguistic choices.

- To investigate the corporations' stance of displaying both positive and negative events in the CARs.

- To explore the inter-discursive appropriation practices in the genre.

\section{Review of Studies}

\section{Studies on Rhetorical Structure}

Several genre-based studies have focussed on the generic features used in different sub-genres of CARs such as the CEO's letter (Xiaoqin, 2017; Dragsted, 2014; Conaway \& Wardrope, 2010), operating and financial review (Rutherford, 2005), tax computation letters (Flowerdew \& Wan, 2006) earnings presentations vs earnings releases (Camiciottoli, 2009), auditors' reports (Flowerdew \& Wan, 2010), CEO's messages (Ngai \& Sing, 2014), and CSR (Ilenia, 2019; Fuoli, 2018; Rajandran \& Taib, 2014). It is also noticed that different sections or different sub-genres of CAR function differently. Some sections have been devoted to promoting a positive image of the company, while some have a primarily informative function (Breeze, 2013, p.87).

One area of research has centered on the rhetorical structure of CEO letters that normally contain the introduction of the report and overview of the company's performance. These letters appeared to be explicitly optimistic and rhetorical (Hyland, 1998; Garzone, 2004, 2005; Breeze, 2012; Fuoli, 2016). Garzone (2004) revealed three move structures in this genre: M1. Evaluating/commenting on company's performance, results and trends in the relevant year, M2. Providing a narrative of salient facts, and M3. Illustrating outlook and priorities for the future, in 10 CEO letters by local Italian companies and 10 from international companies. Von Berg (2013) analyzed the CEO letters of eight top international oil companies issued in CSR reports of 2012. This study found four moves such as M1.Title for the letter, M2. Defining CSR / justifying CSR involvement with a view to changing, M3. Providing a narrative of salient facts (events, operations, figures), and M4. Referring to outlook and priorities for the future. In an innovative study, Bhatia (2008) found 7 moves such as: M1. Overview of the review period, M2. Achievements-measures, M3. Elaboration and explanation of themes, M4. Expectations and promises, M5. Looking forward, M6. Expressions of gratitude (optional), M7. Positive and confident closing, in 15 CEO's letters of companies listed in Hong Kong Stock Exchange within the time period of 1998 to 2005. In conclusion, Bhatia (2008) argued that in a challenging economic environment, the text is embedded specifically in professional context embedded with characteristics of the specific business which strongly project the promotional image of the organizations.

Researchers with regard to genre structure have also expanded this field with numerous studies on different sub-genres of CARs. In these studies, the main conclusion is that communicative purpose of all these genres is to gain the readers' trust and confidence. Nickerson and De Groot (2005) 
INTERNATIONAL JOURNAL OF ACADEMIC RESEARCH IN BUSINESS AND SOCIAL SCIENCES Vol. 10, No. 9, 2020, E-ISSN: 2222-6990 @ 2020 HRMARS

conducted a cross-cultural analysis of chairman statements and CEO statements in British English and Dutch English. The study identified 6 move patterns namely: M1. Business letter layout, M2. Financial performance (past) operations, M3. Financial performance (future), M4. Operations, M5. Strategy, and M6. Credentials. The cross-cultural variation of these sub genres shows that British CEOs statements approach was informational and promotional whereas Dutch CEOs statements were both relational and informational. In an in-depth study, Yeung (2007) explored 22 business reports from different industrial sectors ranging from medium to large enterprises mainly from Hong Kong, the United Kingdom, Singapore, and Malaysia. The researcher found a topical organization of three-step moves such as M1. Findings, M2. Conclusion/Interpretation, and M3. Recommendation. Yeung (2007) postulated that these reports emphasized on the value of theoretical concepts and exemplified this view by comparing the genre in question with research articles whose common feature is to end with suggestions for further reading.

Further, De Groot, (2008) examined three sub genres of CARs namely, operational review, management statement and corporate profile. By a mixture of purposive and cluster sampling, 22 CARs were equally collected from Netherland and England's stock exchange. De Groot (2008) identified 10 moves and 20 strategies in the management forewords genre i.e. M1. Addressing the reader, M2. Anticipating reader orientation, and M3. Salutation to reader strategy. The sub-genre of corporate profiles revealed five moves and eleven strategies. Among the moves, the frequency of occurrence of the move 'Communicating corporate strategy' was higher in Dutch companies than the British companies and this was the significant difference between the two cultures. The subgenre of Operational review consisted of 9 moves and 13 strategies. Significant differences were also found in the operational review of the two nations. For instance, Dutch companies applied the strategy 'General profile of the company' and coordinated sequence of the moves 'Detailing the product', 'Reporting on operational performance' and 'Targeting the market' more often than the British companies. On the other hand, British companies used the move 'Speculating on future performance' significantly. At the end, De Groot (2008) stated that cultural variation is the cause of subtle differences in these sub genres.

Flowerdew and Wan (2010) analyzed 25 audit reports issued in a large international Hong Kong accounting firm. The study came up with eight moves: M1. Opening, M2. Summary of credible actions taken, M3. Address responsibilities, M4. Opinions, M5. Emphatics of matters, M6. Qualified opinion, M7. Disclaimer, and M8. End. The contextual analysis showed the instances of mix languages and immense pressure to improve English and Mandarin spoken skills. On the other hand, Miller et al. (2010) conducted a discourse-based analysis of the corporate governance disclosure genre in the trade and logistics industry for Hong Kong and United States. This study identified 34 moves and several steps in 14 statements on corporate governance. Among these, only 7 moves were found as obligatory moves and others were optional. The obligatory moves were M1. Introduce Report, M2. Board responsibilities, M3. Process for filling a position, M4. Explanation of a specific committee, M5. Information about external/internal audits, M6. Explanation of communications, and M7. Disclosures. Miller et al. (2010) concluded that companies seem to reveal their governing procedure to improve shareholder confidence and in fact, this is the main purpose of this genre. 
Moreover, Mason and Mason (2012) studied the micro and macro linguistic/textual features of 100 environmental reports of 12 listed corporations. The study aimed to examine the positive aspects of these reports, which are highlighted by the micro discursive and macro discursive elements in the reports. Findings revealed two key common moves to represent reporting and promoting functions of this genre i.e. M1. Establishing the company's environmental credentials, and M2. Introducing sustainability initiatives. The findings also revealed that the companies use a hybrid discourse genre with the purpose to influence their audiences at both macro structural and micro structural levels. However, Mobasher and Afida (2015) studied management forwards section of CARs in order to propose a model of move analysis. For this purpose, they selected 64 management forward sections from Bursa Malaysia's main market and 31 from Kuwait's main market stock exchange. This study found six structural moves that were further articulated into nineteen strategies. The revealed moves are M1. Opening the report, M2. Reporting economic environment of the market, M3. Reporting company's financial performance, M4. Reporting company's performance and achievement, M5. Previewing future, and M6. Concluding the letter. The researchers argued that M5. Previewing future that create a positive tone on the profitability of the company might indirectly attract potential investors.

\section{Studies on Lexico-grammatical Features}

Lexico-grammatical features are important to analyze the communicative intentions and meanings of a particular phrase or word in a specific genre. They perform different functions such as persuasion and promotion. Most of the linguistic studies on CARs explored the important role that language plays and looked at the ways companies construct corporate identity and appropriate genres for achieving various communicative intentions. These linguistic studies (Ngai \& Sing, 2017; Fuoli \& Hart, 2018; Bhatia, 2013; Breeze, 2012, 2013; Mason \& Mason, 2012; Fuoli, 2012; Caimotto \& Molino, 2011; Bowers, 2010; Clatworthy \& Jones, 2006; De Groot et al., 2006; Conaway \& Wardrope, 2010; Kohut \& Segars, 1992; Thomas, 1997) have sought out the ways companies construct a positive identity for themselves by using a positive tone, and with the help of positive self-construction strategies such as, application of personal pronouns, processing verbs, use of adjectives and adverbs, focusing on future achievements and use of nominalization or non-human agents and passive construction. By using different language features, corporations are portrayed positively, where corporations claim credit and responsibility for positive events but in the case of negative events they avoid responsibility. Part of the reported positive events are in providing solutions to problems that are faced by companies or businesses (Afida, 2007; 2010; 2013). Notwithstanding, the studies for language features provide substantial knowledge about the lexical and grammatical elements in CARs although these language features are often chosen specifically to convey the specific characteristics about corporations. Research of this kind has linked to a more general psychological phenomenon of human behavior called "the Pollyanna effect". The Pollyanna effect refers to a fact that people have a "universal tendency" to focus on positive language in communication but avoid negative words (Boucher \& Osgood, 1969, p. 6). Another important finding from the studies reveal that companies adopt different strategies in CARs when revealing losses or bad news. They report bad news strategically to distance the top management from these negative messages while circumstances and external reasons are emphasized as a cause of the company's weak performance. To achieve this rhetorical goal, the researchers found that writers often use different lexico-grammatical choices. 
INTERNATIONAL JOURNAL OF ACADEMIC RESEARCH IN BUSINESS AND SOCIAL SCIENCES Vol. 10, No. 9, 2020, E-ISSN: 2222-6990 @ 2020 HRMARS

\section{Positive Tone}

Initially, Hildebrandt and Snyder (1981) analyzed Chairman's statement of 12 corporations to see the positive and negative words in financially good and weak years. Their results revealed two key conclusions. Firstly, the language is predominantly positive no matter what the financial status the organization has. Secondly, in a financially good year of a company, the occurrence of negative words is less frequent than in a bad year. Further, in a corpus based linguistic study on 419 CARs narratives of 44 companies, Rutherford (2005) confirmed the Pollyanna hypothesis by Hildebrandt and Snyder (1981). Rutherford (2005) argued that the positive words occurred more frequently than the negative words even in years of severe financial hardship and regardless of the company's financial performance. In addition, positive connotations are used by less successful companies more often than the successful ones. Based on the word frequencies, the researcher argued that in this genre of accounting narratives, the Pollyanna effect is present in classes of words, individual words, and even in charged words. Furthermore, Thomas (1997) explored the textual differences of the letters to shareholders from 1984 to 1988 of only one company that reflected the substantial change from profitable to unprofitable. Using a systemic approach, she confirmed the previous findings that the overall language of the letters seemed positive regardless of the company's financial situation, and even in the years of loss, the letters to shareholders tend to portray the company as growing. Clatworthy and Jones (2003) revealed the same findings in CEOs statements of 50 UK listed companies, that the improving companies reported good news more often than the bad news and declining companies also pay strong attention on good news and little attention is paid to the bad news, contrary to the statements on company's financial situation. Further, the interesting point was that both types of companies tend to attribute bad news to the circumstances or external factors while, good news to themselves. This fact reflects the company's self-interest or private intentions when reporting news, in order to be perceived favorably. In this context, other relevant studies (Wang et al., 2012; Bhatia, 2013; Alexander, 2009; Aliyyah, 2016) also concluded that positive words are used more frequently than the negative words in CARs. The positive phrases or specific positive words that transmit reassurance and trust are used in the reports of companies with an aim to develop positive impression of the corporations to the readers. Wang et al. (2012) analysis of different sections of CARs also found that corporations use more positive words than the negative words aiming to develop an impression to the readers of the company's success in the near future. These findings also affirm Haslinda and Lehman's (2009) study, who found that only 1 in 50 Malaysian corporations as compared to 12 in 50 Australian corporations report negative news. Similarly, Thompson and Zarina (2004) also found that positive news are reported in $98 \%$ of Malaysian corporations.

\section{Adjectives}

The language of CARs is normally positive and evaluative that mostly emphasizes on the construction of the positive identity of the corporations and its staff. Interestingly, these business reports are found typically persuasive in nature and in order to achieve the persuasive aims, business reports employ various methods such as positive evaluation through adjectives. Often the expert writers of CARs make extensive use of intensifying adjectives as boosters to construct positive corporate identity as outstanding. Adjectives basically function to "expand and elaborate the information presented in a text" (Biber, 1988, p. 237). However, in most of the advertisement and promotional genres, adjectives are used as an indispensable strategy to "describe and positively evaluate 
INTERNATIONAL JOURNAL OF ACADEMIC RESEARCH IN BUSINESS AND SOCIAL SCIENCES Vol. 10, No. 9, 2020, E-ISSN: 2222-6990 @ 2020 HRMARS

products" which can be "the basis of selling power" (Bhatia, 1997, p.188). Previous research on CARs has shown that adjectives as positive word indicators form a pleasant picture in readers' mind (Thomas, 1997; Zanola, 2010; Bhatia, 2012, 2014; Bhatia, A. 2013; Miller et al., 2010; Bernard, 2015). With the help of these evaluative positive adjectives, corporations revealed their states of mind and construct their own personalities as having these moral attributes that ultimately increase their economic development and mitigate the irregular situations. Adjectives at the attributive position enhance the information provided by a noun while, express evaluations of things when used predicatively or at the predicative position (Biber et al., 1999). For example, Bernard (2015) found that corporate writers of the CARs use adjectives at predicative positions as positive connotation words to promote the company, build a relation to the company, relay positive mental processes or experiences, and construct the positive image of a company as knowledgeable and powerful entities. While analyzing the sub genres of CARs Yeung (2007) argued that the main communicative purpose of the adjectives in CARs is to form a pleasant picture of something in reader's minds in order to persuade or convince them on writer's point of view. The positive evaluative aspects of business reports are built up with the use of intensifying adjectives as boosters in different parts of the report. Yeung (2007) pointed out that the interesting position of adjective is the pre-modifying position. In CARs, the use of the various forms of adjectives in predicative positions indicate their status as new information that boost the confidence on the basis of which statements are made (Yeung, 2007). Accordingly, these intensifiers adjectives function to support the writer's positive tone besides inspiring hope and offering trust on their problem-solving solutions. These findings affirm Fuoli (2012), who also found that evaluative adjectives are frequently used by the companies in order to express the approval of their own behavior particularly about their progress. In addition, Miller et al (2010) further emphasized that the use of more personal and qualitative and more quantitative and objective adjectives are used to strengthen shareholders' confidence. In predicative positions, the use of the form of adjectives indicate their status as a new information to boost the confidence based on which statements are made. According to Rajandran (2019), the positive evaluation is also constituted through adjectives such as, 'great' and 'conducive', 'life-saving' initiatives which invoke a positive impact and cements their position "as helping and not harming society" (Rajandran \& Fauziah, 2014a, 2014b). Aliyyah (2016) also found adjectives (the best, flourish, first class, success, committed) as positive word indicators throughout the CSR reports. Moreover, Malawasi (2005) carried out a study on 47 European Banks' CARs published on the web between 1995 and 2002. With the support of WordSmith Tools (Scott, 1999), and a qualitative approach, this study revealed that in these reports, the vast majority of evaluative nouns, adjectives and verbs are included quite inductively to build a positive image. These findings confirm the promotional nature of CARs in addition to the informative one.

\section{Adverbs}

Keeping in mind the persuasive effects, adverbs are also analyzed as an important linguistic feature in corporate writing. Usually, adverbs as an indispensable strategy, serve the function of description in any text. However, in hybrid genres such as CARs apart from description, adverbs provide specific descriptions and extra insight into how something is to be performed, who does something or when something is done, more often to evaluate the text in order to grab readers' attention. Adverbs on different positions such as at predicative and attributive positions in the text enable the language users to modify the claim of adjectives (Biber et al., 1999) and build different positive evaluative 
INTERNATIONAL JOURNAL OF ACADEMIC RESEARCH IN BUSINESS AND SOCIAL SCIENCES Vol. 10, No. 9, 2020, E-ISSN: 2222-6990 @ 2020 HRMARS

effects on the readers' mind. In this regard, Bernard (2015) affirmed that the evaluative statement is an attribute that can be realized by an adjective (good) or adverbs "dreadfully", "wonderfully". Similarly, Fairclough (2003) postulates that confidence or stance could be realized in the sentence through the adverbs (evidently, obviously) and adjectives (probable and possible) which have important implications for the establishment of positive corporate identity and maintaining shareholders' confidence (Fairclough, 2003). These results are also in line with Yeung (2007) who ascertained that the positive evaluative aspects of business reports are built up with the use of adverbs in various attributive and predictive positions and intensifying adjectives as boosters (e.g. 'this certainly is the future'). Interestingly, adverbs signify their function in the form of new information in predicative positions (Yeung, 2007). She views that adjectives and adverbs in different parts of the report support and convey the writer's general positive tone besides inspiring optimism and offering confidence for problem-solving solutions. The use of form of adjectives or adverbs in predicative positions indicate their status as new information and boost the confidence on the basis of which statements are made. The above studies also affirm Miller et al. (2010) view in their analysis of statement on corporate governance genre of CARs that these reports contain the use of more personal and qualitative adjectives and adverbs such as "sincerely" in Hong Kong corpus, while, more quantitative and objective adjectives and adverbs, such as "regularly", in United States strengthen shareholders' confidence. In predicative positions, the use of the forms of adverbs or adjectives indicate their status as new information to boost the confidence based on which statements are made. Rajandran (2019) stated that adverbs such as, 'sincerely' not only humanizes the corporation (Pollach, 2005), but also shows emotions and interest in sustainability.

\section{Pronouns}

Furthermore, some researchers have dealt with the question of the use of pronouns from the aspect of rhetorical application of personal and impersonal expressions. Wang et al. (2012) analysis of different sections of CARs explored the use of pronouns and found them generally more frequent in the chairman's statement. It was found that ' $l$ ', and ' $m y^{\prime}$ ' are used to reduce the distance between the reader and the organization. While, 'we' and 'our' are used to seek the readers' approval. Similarly, Ngai and Singh (2014) studied addresses to stakeholders, and CEOs messages from 234 listed companies in Hong Kong, Shanghai and Taiwan during 2010. The linguistic differences revealed that CEOs messages in these corporations contained frequent use of words like 'lead' and first person pronouns in order to highlight the CEO's leadership role, authority and power to distance himself and the stakeholders. It is important to mention that although the reports tend to use first person pronouns aiming to show the authoritative tone of the leader, they also contained inclusive pronouns such as 'you' and ' $w e$ ' and a variety of engagement words such as 'team spirit' in order to engage stakeholders and reduce the social distance between the stakeholders and the authority. Using a corpus tool, Conaway and Wardrope (2010) identified the stylistic differences of cultures in CEOs' letters where both categories of companies frequently use the pronoun 'our' and ' $w e^{\prime}$ ' instead of ' $I$ ' to deflect the self-promotion of CEOs' letters. Aliyyah (2016) argued that to delimit the distance between the management and shareholders and also to indicate the shared responsibility between the company and the shareholders, personal pronouns 'we', 'our', 'you' and 'your' were used. Garzone (2004) also found that a sense of inclusiveness is developed through personal pronoun ' $w e^{\text {' }}$ and 'our'. The researcher also observed that companies tend to use less first person plural pronouns that referred directly to the writer or sender of the report. Alexander (2009) also recognized the role 
INTERNATIONAL JOURNAL OF ACADEMIC RESEARCH IN BUSINESS AND SOCIAL SCIENCES Vol. 10, No. 9, 2020, E-ISSN: 2222-6990 @ 2020 HRMARS

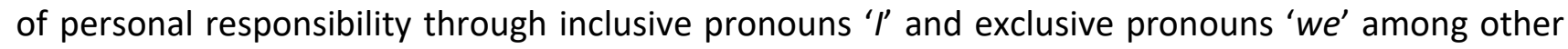
roles.

Additionally, Thomas (1997) found that the use of pronoun 'we' decreased drastically in poorly performing years of the company in order to emphasize the circumstantial factors as well as

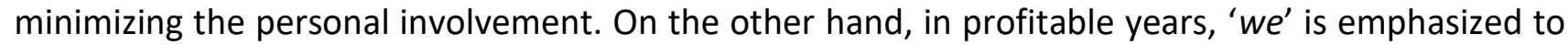
show that company management is responsible for success. Similarly, Clatworthy and Jones (2006) observed the effect of company performance on lexical features in CARs. By using a sample of 200,000 UK companies, the study found that personal references and more precisely the inclusive pronoun 'our' is more likely used in profitable companies than the unprofitable companies. Williams (2008) examined 'mission statements' with the aim to see the present state of this genre. The corpus sampling consisted of 27 mission statements, 13 from high performing companies whereas, 14 from the low performing companies respectively. The findings revealed that positive values are frequently included in these reports. First person, plural forms and positive values are used in these reports as a character-building strategy to show companies' concern for the readers, thereby increasingly identify them with their audiences. Preferably, both group of companies preferred to use first person pronoun. However, high performing companies included first person and plural self-references more often than the lower performing ones. Bernard (2015) states that first person pronoun usage creates solidarity with the readers. First person plural pronouns are used as substitutes of the company's name or for the common phrase "the company". It has three rhetorical purposes: 1 . To make statement on behalf of 'all of us', 2. To make explicit reference to the company which also involve the reader (Fairclough, 2003) and 3. To obscure the speaker's identity (Breeze, 2013). Moreover, Bernard (2015) also found that grammatical construction in corporate governance discourse never assigned a passive role to 'the board' and a phrase 'the board' is frequently used to take the role of an 'agent' or the 'entity' who perform those actions. The phrase 'the board' is usually replaced with

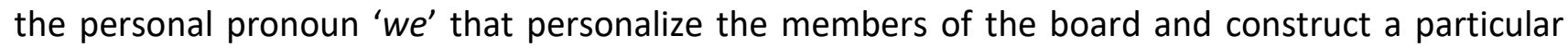
image of the company. In an investigation of a corpus of 137 CEOs statements and 110 directors' letters from CARs, Hyland (1998) found that in CEOs letters, the use of first person pronouns was utilized extensively compared to the director's report. However, in less successful years of those companies, first person pronouns were rarely used. Dragsted (2014) also pointed out that in letter to shareholders of Danske Bank's CARs published during 2004 to 2013 (in three periods of pre, during and post), high frequency of positively charged words is a reflection of a move towards a more engaging and persuasive device in an attempt to rebuild the company's positive relationship with the customers and shareholders e.g. the researcher noted the frequent use of interactional discourse markers particularly self-mentions (first person pronouns) and engagement markers like (personal pronoun you and inclusive we). Another recent study (Rajandran, 2019) investigated CSR webpages in the websites of two largest Malaysian corporations in 2016 and found that although these two corporations belong to two different industries, both corporations practice positive CSR by using specific language and visual features. For instance, using ' $w e^{\prime}$ ', websites depict corporations as responsible citizens which emphasizes their contribution to start and continue initiatives. Conversely, in a study on statement on corporate governance, Miller et al, (2010) found a common pattern in this genre where pronouns are avoided in both countries' reports in order to prevent ambiguities that could confuse the reader or make the information unclear. 
INTERNATIONAL JOURNAL OF ACADEMIC RESEARCH IN BUSINESS AND SOCIAL SCIENCES Vol. 10, No. 9, 2020, E-ISSN: 2222-6990 @ 2020 HRMARS

\section{Passive Voices}

Passive voice is also one of the most frequent and important grammatical choices of the corporate disclosure documents because it serves various communicative functions. First, corporations use passive voice as a face saving strategy by creating a depersonalized, authoritative, objective and impersonal professional text (Yeung, 2007; Garzone, 2004) which are basic attributes of the professional and scientists' discourse (Yeung, 2007). Second, in professional context, the use of agentless passive voices divorce the action from the doer of the action and deletes the presence of doer or allocate blame to external forces (Clatworthy \& Jones, 2003; Thomas, 1997; Subramanian, et al., 1993). This rhetorical action of agent omission is significantly found in professional discourse. For a professional discourse community, "the effect of emphasizing what was done rather than who did it" (Anspach, 1988, p.366; Helan, 2012, p.144) is more important. In this regard, the attention is diverted to the action while the doer of the action or major decisions that lead to that action are deflected. This function appears more significantly when it is used to report problematic and adverse circumstances such as financial crises. Thomas (1997), while analyzing a series of management's letters of one company during a five-year period, observed an increase in the number of passive constructions from $10 \%$ to $15 \%$ in 1984 (a profitable year) to $20 \%$ to $21 \%$ in 1988 (a loss-making year). In this context, the interesting point is that the changes in terms of language use especially to avoid becoming negative news were initiated to show a factual, 'objective' situation caused by circumstances not attributable to any persons who might otherwise be thought responsible' (Thomas, 1997, p.47). Similarly, Cen and Cai (2014) investigated chairman's statements chosen from most and least profitable (divided as top 50, bottom 50 and a middle range group) 50 companies of Australia. It was found that voluntary reporting in these reports of the most and less profitable companies contained textual differences as well as exaggeration or information concealment whereby, passive voices were used more to increase the extent of company profit and corporate complexity as represented by the number of segments. While investigating CEOs letters to shareholders from listed U.S companies and Latin American companies, Conaway and Wardrope (2010) also found double quantities of passive construction revealing the characteristics of highcontext of cultures, 'uncertainty reduction, and interpersonal warmth'. Regarding the use of passive sentence constructions, the researchers ascertained that they function to "defray concerns about political and economic issues, and to emphasize on courtesy" (Conaway \& Wardrope, 2010, p.164). In a comparative pilot study on 10 CEOs letters to shareholders from local (Italian) companies and 10 CEOs letters from international (American and European) companies, Garzone (2004) also found that Italian reports frequently used passive voices to show their objective style. Similarly, Yeung, (2007) also ascertained that to keep the tenor of the reports rational, passive voice is more often used while giving suggestions and opinions which helps to hide someone's own responsibility or accountability and to develop an objective tone (Yeung, 2007). In her concluding remarks, Yeung (2007) illustrated that there seems to be clear evidence that specific intertextual features of scientific reports borrowed in these business reports that act as an immanent rhetorical force. Authors employ these different grammatical structures depending on their purpose, whether for persuasion or information.

\section{Nominalizations}

The positive or negative values of an environment can also be developed with better choices of nouns and verbs (Halliday, 2001; Schultz, 2001). Nouns might experience nominalization that 'together with non-human participants' can give the appearance of 'objectivity' in the writing style. Nominalization 
is defined as the noun form of adjectives and verbs that typically end with "ion", "ment", "ness", "ance" or "ence" (Moffitt \& Burns, 2009). Examples include contribution, commitment, effectiveness, and performance. It is a grammatical process where a verb, adverb, or an adjective can be the head of a noun phrase, or a noun is produced from a different parts of speech by derivational affixes, that "represents social actors and social processes in particular ways that can be linked to ideologies on behalf of the text producers" (Bernard, 2015, p.68). The textual evidence in the use of nominalization in various parts of the report functions to avoid the personal blame and hide the real issue and create distance to the real matter, while keeping the voice of the text as professional and impersonal, which therefore maintains an objective and rational tone (Alexander, 2009; Thomas, 1997; Yeung, 2007; Bhatia, 2008). Bhatia (1993) considered the nominal expressions in legal documents as an extremely formal language that express the truth and facts of object accurately. Nominal expressions in business discourse and professional genres function persuasively and play several ideological functions such as, to delete agency, reify abstract concepts, make reified concepts appear as agents, and finally, to maintain unequal power relations (Bhatia, 1994; Billig, 2008). By combining qualitative critical discourse analysis with quantitative corpus linguistic techniques, Alexander (2009) investigated how politicians and corporate representatives talk about sustainability issues using positive words and nominalization. It was found that nominalized words are preferred in order to determine the situation as "an abstract, merely technical problem" and to hide the real issue and create distance to the real matter (Alexandar, 2009, p.19). Regarding the choice and function of nominalization, Yeung (2007) conducted an in depth study on twenty-two business reports collected from different industrial sectors including, utilities, hotel, transportation, banking, retail, and computer technologies mainly from Hong Kong including the United Kingdom, Singapore, and Malaysia. This study found that the use of nominalization in headings and in different parts of the report functions to avoid the personal blame, by keeping the voice of the text professional and impersonal. It maintains an objective and rational tone. Another very interesting study by Bhatia (2008) investigated CARs of fifteen companies listed in Hong Kong Stock Exchange. This study was inspired from the 2001 Enron's collapse. It was found that in challenging economic environment, the typical evidences of nominalisation within the move structure of the genre indicate that the text is embedded specifically in professional context, which strongly project the promotional image of the organizations. As for the function of nominalization, Bhatia (2008) agreed with Thomas (1997) that it is a very useful device as it is used to communicate weak performances and give the subtle impression of a factual situation where a problem with the company is not attributed to any person but rather to circumstances. In conclusion, the researcher argued that "it is not simply that a professional genre is constructed and used for a specific professional purpose; it may be that a specific genre is deliberately and consciously bent to achieve something more than just a socially accepted and shared professional objective" (Bhatia, 2008, p.174).

\section{Action Verbs}

Over years, some studies have been conducted on action verbs. These active verbs appeared to be largely used by corporate business people to represent the company's image as an active entity and to display a more positive and forceful image of the corporations (Mason \& Mason, 2012; Aliyyah, 2016). These specific linguistic features are used as discursive strategies to construct a trustworthy image and evaluative beliefs in stakeholders and readers. They establish cohesiveness to the genre by conveying the company's actions and elevating the positive effects of such actions. Mason and 
INTERNATIONAL JOURNAL OF ACADEMIC RESEARCH IN BUSINESS AND SOCIAL SCIENCES Vol. 10, No. 9, 2020, E-ISSN: 2222-6990 @ 2020 HRMARS

Mason (2012) studied micro and macro linguistic/textual features of 100 CERs from 12 companies. It was found that specific linguistic features are used as discursive strategies to construct a trustworthy image and evaluative beliefs in the mind of stakeholders and readers. For instance, action verbs such as adopted, reduce, limit, minimize, preserve, develop and produce correlated with the six types of sub-moves that represent the company image as an actionable entity (Mason \& Mason, 2012, p.479). With this discursive strategy, companies not only inform audiences as guardians of the situation, but also meet the cognitive requirements for successful ideological inducement (Mason \& Mason, 2012) and encapsulate a sense of trust among the readers. In this context, Thomas (1997) stated that this specific type of verbs dominate in business CARs because it suggests growth and progressive processes of the corporations. Moreover, the results of Thomas (1997) also indicated an increase of objectivity of the message as profits fall with an increase in the use of relational 'being' verbs, processing verbs, and non- human agents. It was also found that during loss making, there was a noticeable decrease in the usage of doing verbs or action verbs. Additionally, while exploring the inter-textual and inter-discursive analysis of twenty corporate environmental report (CERs) sections of CAR, Aliyyah (2016) ascertained that active verbs such as 'adhere', 'compliance', 'continues', 'focusing on', are commonly found in these reports to display an assertive and more positive image of the company as growing, progressing and active. Although there is a lack of comprehensive explanation which show how they carried out those intentions (Aliyyah, 2016), corporations' success indicate a positive image of the company which helps in putting the company in a favorable light. Moreover, Bhatia's (2013) study on Petro China CSR reports from 2008-2011 reiterated that verbs like 'adhere', 'compliance' 'continues', 'focusing on', 'minimise', are often associated in these reports with 'intentions to act' rather than 'actions taken'. With the help of action verbs and in conjunction with nouns of intentions, these reports portray companies as constantly progressive, growing, and developing entities which consequently claim goodwill from audiences. However, these statements according to Bhatia (2013, p.323), "are merely statements of perspective, which are vague in detailing how or when those intentions will be realized". These features are also associated with promotional discourse rather than just a reporting discourse (Bhatia, 2013).

\section{Tenses}

Previous research has also shown interesting insights on the time sequences. Kohut and Segars (1992) examined letters to shareholders from 25 top performing and 25 poor performing companies by employing content analysis. The study resulted in several interesting findings for example, the CARs of high performance companies tend to be wordier overall and more elaborated than the poor performance CARs, whereas the low performance reports are presented in fewer words. Further, the high performers seemed to make past references and low performers used future tense mostly to incline themselves towards future opportunities instead of poor past financial results. However, the overall results of both groups show that the past references were highly common than the future ones because companies' management preserves their credibility through discussing their known past rather than the unknown future. Malawasi (2005) while investigating the sections of CARs such as, Corporate Governance Description, Chairman's Statement, Chief Executive's Report, and Bank and Business Description elaborated that to persuade the readers of CARs, another interesting aspect is the emphasis put on future projects and performances thus diffuse CARs as a persuasive genre that confirms the promotional nature of CARs in addition to being informative. In terms of lexicogrammatical features, Clatworthy and Jones (2006) elaborated that unprofitable companies refer and 
emphasize more on their future as compared to the profitable ones. They concluded that through such rhetorical strategies, managers try to divert the attention of the readers from the current unsatisfactory results and emphasized good news to reduce market response. Bhatia (2008) also found extensive use of perfect and future tenses. In challenging economic environment, the use of perfect and future tense forms within the move structure of the genre indicate that the text is embedded specifically in professional context, which show the embedded characteristics of specific business context that strongly project the promotional image of the organizations. Heiniluoma (2008) formulated a study on the CEOs letters of 11 American corporations represented companies in their 11 good years and 12 bad years respectively. Findings have shown that an assertive tone is predominantly used in future-related portions of these reports. It is reported that through this tone, companies attempt to convince the reader and depict the future positively. Aliyyah (2016) ascertained that past, perfect tenses and positive word choices are paired with nominals such as business practices, active measures, business performance to embed the text in a specific business context. It is interesting to note that companies' good performances and achievements are presented in the past tense and perfect tense with a lengthy elaboration. However, weak or dismal performance is presented briefly and advances towards future events or predictions in a promotional way are used to project a 'forward-looking' image of the companies.

\section{Conclusion}

The findings of the reviewed studies on CARs confirmed that regardless of the company performance, the universal tendency to use positive words than negative ones is frequent. With the help of positive language features and positive evaluative words such as adjectives, adverbs and action verbs, the writers of professional discourse embellish the company's reputation by minimizing and avoiding company responsibility on negative aspects but claim credit and recognition for positive events. Bad news is used strategically to distance the top management from these negative messages while bad circumstances and external reasons are emphasized as a cause if the companies suffer from poor performance. They use different strategies to reveal losses and bad news e.g. use of processing verbs and inanimate nominal group, nominalization, passive construction, and highlight future achievements. Another important finding in these studies is that there is variation in successful companies and loss making companies regarding their language style and content. Moreover, CARs are basically reporting genres and structurally different from other promotional genres. However, nowadays intentionally inter-discursive appropriations are done in order to make this genre to be both reporting and promotional like advertisements or book blurbs. Hence, the specialists generate a mixed genre of reporting and promoting. In sum, the findings of this paper revealed that the companies use a hybrid genre with the purpose of influencing their audiences at both macro and micro structural levels. Specific linguistic features alongside the rhetorical structure analyses are used as discursive strategies to construct a trustworthy image and evaluative beliefs in the mind of the readers.

This review paper contributes numerous implications for both researchers and practitioners. First, the findings of the relevant past studies that exhibit how corporate professionals disseminate and consume professional knowledge and exploit available semiotic resources to achieve their professional goals (Bhatia, 2004) would help its readers to further understand the critical genre theory. Second, the construction of interdiscursive practices of appropriating the business discourse 
INTERNATIONAL JOURNAL OF ACADEMIC RESEARCH IN BUSINESS AND SOCIAL SCIENCES Vol. 10, No. 9, 2020, E-ISSN: 2222-6990 @ 2020 HRMARS

for private intentions are precisely presented that enriches the existing theoretical knowledge of the researchers and corporate writers in the fields of applied linguistics and business communication. Third, novice corporate writers would be benefited by knowing how the choices of linguistic features at different contexts can perform various communicative functions. Last, the extensive review of studies on CARs can benefit both novice and expert researchers who want to pursue their research on CARs and its sub-genres from linguistic standpoint.

\section{References}

Afida, M. A. (2007). Semantic fields of problem in business English: A corpus-based study on Malaysian and British journalistic business texts. Corpora: Corpus-based Language Learning, Language Processing and Linguistics, 2(2), 211-240.

Afida, M. A. (2010). "Help, change, plan - A corpus analysis of key semantic domains in business solutions. Jurnal Bahasa Jendela Alam, 6, 831-844.

Afida, M. A. (2013). Combining problem-solution categories and communicative acts: An analysis of Malaysian and British business journalistic texts. World Applied Sciences Journal 21 (Special Issue of Studies in Language Teaching and Learning), 174-185.

Aliyyah, F., N. (2016). Interdiscursive analysis of corporate environmental reports of oil and gas companies in Malaysia. Unpublished Dissertation: University of Malaya.

Alexander, R. J. (2009). Framing discourse on the environment: A critical discourse approach. New York: Routledge.

Ali, S. M., \& Isa, M. A. (2018). Firms attributes and corporate social responsibility disclosure: literature review. International Journal of Academic Research in Business and Social Sciences, $8(4), 310-322$.

Anspach, R. R. (1988). Notes on the sociology of medical discourse: The language of case presentation. J Health Soc Behav; 29, 357-75.

Basu, K., \& Palazzo, G. (2008). Corporate social responsibility: A process model of sense making. Academy of Management Review, 33 (1), 122-136.

Beattie, V., Dhanani, A., \& Jones, M. (2008). Investigating presentational change in UK annual reports: A longitudinal perspective. Journal of Business Communication, 45(2), 181-222.

Bernard, T. (2015). A critical analysis of corporate reports that articulate corporate social responsibility. Dissertation: Stellenbosch University.

Billig, M. (2008). The language of critical discourse analysis: The case of nominalization. Discourse \& Society, 19(6), 783-800.

Bhatia, V. K. (1993a). Analysing genre: Language use in professional settings. Essex: Longman Group Ltd.

Bhatia, V. K. (1994). Generic integrity in professional discourse. Text and talk in professional contexts. In B. L. Gunnarsson, P. Linell, \& B. Nordberg, (Eds.), Skriftsrie, 6 (pp. 61-76). Uppsala, Sweden: ASLA.

Bhatia V. K. (1995). Genre-mixing in professional communication: The case of 'private intentions' vs. 'socially recognised purposes', in P. Bruthiaux, T. Boswood, \& B. Bertha, (eds.), Explorations in English for Professional Communication, City University of Hong Kong: Hong Kong.

Bhatia, V. K. (1997). Genre analysis - step by step. Journal of Linguistics, (19), 207-240.

Bhatia, V. K. (2004). Worlds of written discourse: A genre-based view. Continuum.

Bhatia, V. K. (2008b). Towards critical genre analysis. In Bhatia, V., Flowerdue, J. \& Jones, R. (Eds.), 
INTERNATIONAL JOURNAL OF ACADEMIC RESEARCH IN BUSINESS AND SOCIAL SCIENCES

Vol. 10, No. 9, 2020, E-ISSN: 2222-6990 @ 2020 HRMARS

Advances in Discourse Studies, (166-177). NY: Routledge.

Bhatia, V. K. (2008c). Genre analysis, ESP and professional practice. English for Specific Purposes, 27(2), 161-174.

Bhatia, V. K. (2010). Interdiscursivity in professional communication. Discourse \& Communication, $4(1), 32-50$.

Bhatia, A. (2012). The corporate social responsibility report: The hybridization of a 'confused' genre. IEEE Transactions on Professional Communication, 55(3), 221- 238.

Bhatia, A. (2013). International genre, local flavour: Analysis of PetroChina's corporate and social responsibility report. Revista Signos, Estudios de Lingüítica, 46 (83), 307-331.

Biber, D. (1988). Variation across speech and writing. New York, NY Cambridge University Press.

Biber, D., Johanson, S., Leech, G., Conrad, S., \& Finegan, E. (1999). Longman grammar of spoken and written English. Harlow: Pearson Education.

Bowers, T. (2010). From image to economic value: A genre analysis of sustainability reporting. Corporate Communications: An International Journal, 15 (3), 249 - 262.

Breeze, R. (2012). Legitimation in corporate discourse: oil corporations after deep water Horizon. Discourse \& Society, 23(1), 3-18.

Breeze, R. (2013). Corporate Discourse. Bloomsbury.

Camiciottoli, B. C. (2009). "Just wondering if you could comment on that": Indirect requests for information in corporate earnings calls. Text \& talk, 29 (6), 661-681.

Caimotto, M.C. \& Molino, A. (2011). Greenwashing: A case study. CADAAD, 5 (1), 1-16.

Camiciottoli, B. C. (2011). Ethics and ethos in financial reporting: Analyzing persuasive language in earnings calls. Business Communication Quarterly, 74 (3), 298-312.

Cen, Z., \& Cai, R. (2014). Preference in presentation or impression management: A comparison study between chairmen's statements of the most and least profitable Australian companies. Australasian Accounting, Business and Finance Journal, 8(3), 3-22.

Clatworthy, M., \& Jones, M. (2003). Financial reporting of good and bad news: evidence from accounting narratives. Accounting and Business Research, 33(3), 171-185.

Clatworthy, M., \& Jones, M. (2006). Differential patterns of textual characteristics and company performance in the chairmen's statement. Accounting, Auditing and Accountability Journal, 19 (4), 493-511.

Conaway, R. N., \& Wardrope, W. J. (2010). Do their words really matter? Thematic analysis of U.S. and Latin American CEO Letters. Journal of Business Communication, 47(2), 141-168.

Dafouz-Milne, E. (2008). The pragmatic role of textual and interpersonal metadiscourse markers in the construction and attainment of persuasion: A cross-linguistic study of newspaper discourse. Journal of Pragmatics, 40(1), 95-113.

Dang, T. T. H., Nguyen, T. T. L., Le, K. N., Nguyen, T. H. T., \& Pham, T. B. C. (2020). The information gap in corporate annual reports: Evidence from Veitnam. Accounting, 6, 899-912.

De Groot, E., Korzilius, H., Ickerson, C., \& Gerritsen, M. (2006). A corpus analysis of text themes and photographic themes in managerial forewords of Dutch-English and British annual general reports. Professional Communication, 49(3), 217-235.

Ditlevsen, M. G. (2012). Revealing corporate identities in annual reports. Corporate Communications: An International Journal, 17(3), 379-403.

Dragsted, B. (2014). A case study of letters to shareholders in annual reports before, during and after the financial crisis. LSP Journal, 5(2), 84-104. 
INTERNATIONAL JOURNAL OF ACADEMIC RESEARCH IN BUSINESS AND SOCIAL SCIENCES

Vol. 10, No. 9, 2020, E-ISSN: 2222-6990 @ 2020 HRMARS

Flowerdew, J., \& Wan, A. (2006). Genre analysis of tax computation letters: How and why tax accountants write the way they do. English for Specific Purposes, 25(2), 133-153.

Flowerdew, J., \& Wan, A. (2010). The linguistic and the contextual in applied genre analysis: The case of the company audit report. English for Specific purposes, 29(2), 78-93.

Fuertes-Olivera, P. A., Velasco-Sacristán, M., Arribas-Baño, A., \& Samaniego- Fernández, E. (2001). Persuasion and advertising English: Metadiscourse in slogans and headlines. Journal of Pragmatics, 33 (8), 1291-1307.

Fuoli, M. (2012). Assessing social responsibility: A quantitative analysis of appraisal in BP's and IKEA's social reports. Discourse \& Communication, 6(1), 55-81.

Fuoli, M. (2018). Building a trustworthy corporate identity: A corpus-based analysis of stance in annual and corporate social responsibility reports. Applied Linguistics, 39(6), pp. 846-885.

Fuoli, M., \& Hart, C. (2018). Trust building strategies in corporate discourse: an experimental study. Discourse \& Society, 29(5), pp. 514-552.

Frownfelter-Lohrke, C., \& Fulkerson, C. L. (2001). The incidence and quality of graphics in annual reports: An international comparison. International Journal of Business Communication, 38(3), pp. 337-357.

Frownfelter-Lohrke, C., \& Fulkerson, C. L. (2001). The incidence and quality of graphics in annual reports: An international comparison. Journal of Business Communication, 38(3), 337-358.

Garzone, G. (2004). Annual company reports and CEO's letters: Discoursal features and cultural markedness in C. Candlin and M. Gotti (Eds): Intercultural Aspects of Specialized Communication (pp. 311-343). Peter Lang.

Garzone, G. E. (2005). Letters to shareholders and chairman's statements: Textual variability and generic integrity. Institutional Research Informational System, 3, 179-204

Goel, A., Chakrabarti, A. (2010). Prevalence and sociodemographic correlates of substance use in a rural community in Sikkim, North East India: Results from a pilot population survey. J Subst Use, 15, 13-23.

Grabe, W., \& Kaplan, R. B. (1997). Theory and practice of writing. Longman: London.

De Groot, E. (2008). English annual reports in Europe. Dissertation: University of LOT Netherland.

Halliday, M. (2001). New ways of meaning. In A. Fill, \& P. Mühlhäusler (Eds.), The ecolinguistics reader (pp. 175-202). London: Continuum.

Halliday, M., \& Matthiessen, C. (2014). Halliday's introduction to functional grammar (4th Eds.). London, England: Routledge.

Haslinda, Y., \& Lehman, G. (2009). Corporate environmental reporting through the lens of semiotics. Asian Review of Accounting, 17 (3), 226 - 246.

Heiniluoma, M. (2008). Boosting future prospects or softening promises of success ? The use of emphatics and hedging in the letter to shareholders sections of annual reports. English for Specific Purposes, 38 (2), 135-148.

Helan, R. (2012). Analysis of published medical case reports: Genre-based studies. Unpublished Dissertation, Masaryk University.

Henry, A., \& Roseberry, R. (2001). A narrow-angled corpus analysis of moves and strategies of the genre: Letter of application. English for Specific Purposes, 20(2), 153-167.

Hildebrandt, H. H., \& Snyder, R. (1981). The Pollyanna hypothesis in business writing: Initial results, suggestions for research. Journal of Business Communication, 18 (1), 5-15.

Hyland, K. (1998). Exploring corporate rhetoric: Metadiscourse in the CEO's letter. Journal of Business 
INTERNATIONAL JOURNAL OF ACADEMIC RESEARCH IN BUSINESS AND SOCIAL SCIENCES Vol. 10, No. 9, 2020, E-ISSN: 2222-6990 @ 2020 HRMARS

Communication, 35(2), 224-244.

Jameson, S. M. (2000). Recruitment and training in small firms. Journal of European Industrial Training, 24(1), pp. 43-49.

Kohut, G. F., \& Segars, A. H. (1992). The president's letter to stockholders: An examination of corporate communication strategy. Journal of Business Communication, 29(1), 7-21.

Krishnan, G., \& Parsons, L. (2008). Getting to the bottom line: An exploration of gender and earnings quality. Journal of Business Ethics, 78(1), 65-76.

Li, F. (2008). Annual report readability, current earnings, and persistence. J. Account. Econ, 45(1), 221-247.

Maat, H. P. (2007). How promotional language in press releases is dealt with by journalists: Genre mixing or genre conflict? Journal of Business Communication, 44(1), 59-95.

Malavasi, D. (2005). Banks' annual reports: An analysis of the linguistic means used to express evaluation. Proceedings of the Association for Business Communication 7th European Convention.

Malavasi, D. (2010). The multifaceted nature of banks' annual reports as informative, promotional and corporate communication practices. In: Evangelisti-Allori, P. and Garzone, G. (eds) Discourse, Identities and Genres in Corporate Communication: Sponsorship, Advertising and Organizational Communication. Bern: Peter Lang, 211-234.

Mason, M., \& Mason, R. D. (2012). Communicating a green corporate perspective: ideological persuasion in the corporate environmental report. Journal of Business and Technical Communication, 26(4), 479-506.

Merkl-Davvies, D. M., \& Koller, V. (2012). 'Metaphoring' people out of this world. A critical discourse analysis of a chairnan's statement of a UK defence firm. Acounting Forum, 36 (3), 178-193.

Miller, C., Rasco, M., Tripp, E. (2010). Corpus-based investigation of discourse organization and lexicogrammar: Comparison of Hong Kong and United States corporate governance reports. Dissertation: City University of Hong Kong.

Mobasher, A., Afida, M. A., Faiz, S. A., \& Chan, M. Y. (2013). Review of studies on corporate annual reports during 1990-2012. International Journal of Applied Linguistics and Literature, 2(2), 133-141.

Mobasher, A., \& Afida, M. A. (2015). Exploring the macrostructure of management forewords of corporate annual reports. International Journal of Applied Linguistics and English Literature, $4(1), 1-12$.

Moffitt, K., \& Burns, M. B. (2009). What does that mean? Investigating obfuscation and readability cues as indicators of deception in fraudulent financial reports. Fifteenth Americas conference on information systems, San Francisco, CA.

Myskova, R., \& Hajek, P. (2019). Relationship between corporate social responsibility in corporate annual reports and financial performance of the US companies. Journal of International Studies, 12(1), 269-282.

Nickerson, C., \& De Groot, E. (2005). Dear shareholder, dear stockholder, dear stakeholder:The business letter genre in the annual general report. In P. G. M. Gotti, (Ed.), Genre variation in business letters (pp. 325-346). Bern: peter Lang.

Ngai, C. S. B., \& Singh, R. G. (2014). Communication with stakeholders through corporate web sites: An exploratory study on the CEO messages of major corporations in greater China. Journal of Business and Technical Communication, 28(3), 352-394. 
INTERNATIONAL JOURNAL OF ACADEMIC RESEARCH IN BUSINESS AND SOCIAL SCIENCES Vol. 10, No. 9, 2020, E-ISSN: 2222-6990 @ 2020 HRMARS

Ngai, C. S. B., \& Sing, R. G. (2017). Move structure and communicative style of leaders' messages in corporate discourse: A cross-cultural perspective. Discourse \& Communication, 11(3), 276295.

Palmer-Silveira, Juan, C., Miguel, F., \& Ruiz- Garrido, (2007). Annual reports in the English for business communication classroom: Methodological perspectives. English for Specific Purposes: Studies for classroom development and implementation, 149-171.

Parshakov, P., \& Shakina, E. (2020). Do companies disclose intellectual capital in their annual reports? New evidence from explorative content analysis. Journal of Intellectual Capital.

Parsons, R. (2008). We are all stakeholders now: the influence of western discourses of "community engagement" in an Australian Aboriginal community. Critical Perspectives on International Buisness, 4 (3), 99-126.

Pelikanova, R. M. (2019). Corporate social responsibility information in annual reports in the EU-A Czech case study. Sustainability, 11, 1-21.

Pollach, I. A. (2005). A typology of communicative strategies in online privacy policies: Ethics, power, and informed consent. Journal of Business Ethics, 62, 221-235.

Rajandran, K., \& Taib, F. (2014a). The representation of CSR in Malaysian CEO statements: a critical discourse analysis. Corporate Communications, 19(3), 303.

Rajandran, K., \& Fauziah T. (2014b). Disclosing compliant and responsible corporations: CSR performance in Malaysian CEO Statements. Gema Online Journal of Language Studies, 14(3), 143-157.

Rajandran, A. K. (2015). A critical discourse analysis of Malaysian corporate social responsibility reports. Dissertation: University of Malaya, Malaysia.

Rajandran, K. (2019). Multimodal CSR disclosure in Malaysian corporate websites. Pertanika J. Soc. Sci. \& Hum, 27 (2), 787 - 801.

Rutherford, B. A. (2005a). Genre analysis of corporate annual report narratives: A corpus linguisticsbased approach. Journal of Business Communication, 42(4), 349-378.

Schultz, B. (2001). Language and the natural environment. In A. Fill \& P. Mühlhäusler (Eds.), The ecolinguistics reader. (pp. 109-115). London: Continuum.

Skulstad, A. (2008). 'Creating a green image in the public sphere: Corporate environmental reports in a genre perspective'. In Wodak, R. and Koller, V. (Eds.) Handbook of Communication in the Public Sphere, (pp. 181-201). De Gruyter Mouton.

Skulstad, A. (2010). Creating a "green" image in the public sphere: Corporate environmental reports in a genre perspective. In Wodak, R. \& V. Koller, (eds.). Handbook of Communication in the Public Sphere. Berlin: (pp. 181-202) Walter de Gruyter.

Stallworth, W. L. (2008). The mission statement: A corporate reporting tool with a past, present, and future. Journal of Business Communication, 45(2), 94-119.

Subramanian, R., Insley, R. G., \& Blackwell, R. D. (1993). Performance and readability: A comparison of annual reports of profitable and unprofitable corporations. International Journal of Business Communication, 30(1), 49-61.

Surdu, F. B., Caliskan, A. O., \& Esen, E. (2020). Human resource disclosures in corporate annual reports of insurance companies: A case of developing countries. Sustainability, 12, 1-20.

Swales, J. M., \& Rogers, P. S. (1995). Discourse and the projection of corporate culture: the mission statement. Discourse \& Society, 6, 223-242. 
INTERNATIONAL JOURNAL OF ACADEMIC RESEARCH IN BUSINESS AND SOCIAL SCIENCES

Vol. 10, No. 9, 2020, E-ISSN: 2222-6990 @ 2020 HRMARS

Tardy, C. M. (2003). A genre system view of the funding of academic research. Written Communication, 20 (1), 7-36.

Tom, B. (2010). From image to economic value: A genre analysis of sustainability reporting. Corporate Communications: An International Journal, 15(3), 249-262.

Thomas, J. (1997). Discourse in the marketplace: The making of meaning in annual reports. Journal of Business Communication, 34(1), 47-66.

Thompson, P., \& Zarina, Z. (2004). CSR reporting in Malaysia. The Journal of Corporate Citizenship, $13,125-136$.

Thompson, P., \& Zakaria, Z. (2004). Corporate social responsibility reporting in Malaysia: progress and prospects. The Journal of Corporate Citizenship, 13, 125-136.

Tonetti, I. (2019). Linguistic trust building strategies in Swiss banks' public discourse: A diachronic study of annual reports and corporate responsibility reports from UBS and credit Suisse. Dissertation: Dalarna University.

Vithana, K., Soobaroyen, T., \& Ntim, C. G. (2019). Human resource disclosures in UK corporate annual reports: To what extent do these reflect organizational priorities towards labour. Journal of Business Ethics.

Von Berg, M. (2013). CEO letters in CSR reports: Oil companies in focus. Unpublished Dissertation: Aalto University School of Buisness.

Wang, H., Li, L., \& Cao, J. (2012b). Lexical features in corporate annual reports: a corpus-based study. European Journal of Business and Social Sciences, 1(9), 55-71.

Wang, J. L. (2016). Literature review on the impression management in corporate information. Disclosure Modern Economy, 7, 725- 731.

Wu, J. G. (2012b). Review of the studies on interdiscursivity. Foreign Languages and their Teaching, $2,17-22$.

Xiaoqin, L. (2017). Exploring the rhetorical use of interactional metadiscourse: A comparison of letters to shareholders of American and Chinese financial companies. English Language Teaching, 10(7), 232-241.

Yeung, L. (2007). In search of commonalities: Some linguistic and rhetorical features of business reports as a genre. English for Specific Purposes, 26(2), 156-179.

Zanola, A. (2009). The annual report: An interdisciplinary approach to a 'contaminated' new genre. Presented at the International Conference on "Genre on the Move. Hybridization and Discourse Change in Specialized Communication", at Universitá Federico II, Napoli, Italy. 